\title{
STUDI EVALUASI PONDASI TIANG PANCANG (SPUN PILE) DENGAN PONDASI TIANG BOR (BORED PILE) PADA GEDUNG KANTOR PEMERINTAH KABUPATEN LAMONGAN
}

\author{
Dwi Kartikasari ${ }^{1}$; Deny Sanhadi ${ }^{2}$ \\ ${ }^{1,2}$ Fakultas Teknik Universitas Islam Lamongan. \\ email: dkartika27@gmail.com ; sanhadi.sh@gmail.com
}

\begin{abstract}
Foundation planning must be done carefully and correctly. The foundation's planning aims to compare the axial force acting with the carrying capacity of the foundation between the original foundation that made the pile and the pile in the construction of the Lamongan Regency Government office building to get safe control. The carrying capacity of the foundation is planned to use Standard Penetration Test (SPT) data. The initial calculation of the loading analysis includes dead load, live load and earthquake. These costs are combined and then analyzed with the Staad.Pro program. Calculation of reduction using the reduction method in clay. Calculation of pile cap and foundation using SNI 1726-2012. The output of the Staad.Pro program is obtained axial force in the column which is reviewed at $1260 \mathrm{kN}$. The carrying capacity of a single pole with a diameter of $40 \mathrm{~cm}$ with a depth of $20 \mathrm{~m}$ was obtained by compressive strength of $431.49 \mathrm{kN}$. Taking into account the efficiency figures obtained by the carrying capacity (Qg) of $1715.52 \mathrm{kN}>1260 \mathrm{kN}$, so that they meet the requirements. D16-125 mm flexural amplifier is planned to hold the moment in the pile cap that occurs at $211.6 \mathrm{kN}-\mathrm{m}$. Decrease in total (St) is a decrease in total direct (Si) and decrease in consolidation (Sc) that is $1.673<15 \mathrm{~cm}$. The total reduction (St) on the group pole meets the conditions permitted for the building based on RSNI Geotechnical.
\end{abstract}

Keywords: Foundation carrying capacity, Pile cap, Group drop, Bored Pile

\begin{abstract}
ABSTRAK
Perencanaan fondasi harus dilakukan dengan cermat dan benar. Perencanaan yayasan ini bertujuan untuk membandingkan gaya aksial yang bertindak dengan daya dukung yayasan antara yayasan asli yang membuat tiang pancang dan tiang pancang pada konstruksi gedung kantor Pemerintah Kabupaten Lamongan untuk mendapatkan kontrol yang aman. Daya dukung yayasan direncanakan untuk menggunakan data Uji Penetrasi Standar (SPT). Perhitungan awal analisis pemuatan meliputi beban mati, beban hidup, dan gempa bumi. Biaya-biaya ini digabungkan kemudian dianalisis dengan program Staad.Pro. Perhitungan reduksi menggunakan metode reduksi dalam tanah liat. Perhitungan pile cap dan pondasi menggunakan SNI 1726-2012. Output dari program Staad.Pro diperoleh gaya aksial di kolom yang ditinjau pada $1260 \mathrm{kN}$. Daya dukung tiang tunggal diameter tiang $40 \mathrm{~cm}$ dengan kedalaman $20 \mathrm{~m}$ diperoleh kuat tekan 431,49 kN. Dengan memperhitungkan angka efisiensi yang diperoleh kelompok daya dukung (Qg) dari 1715,52 kN>1260 kN, sehingga memenuhi persyaratan. Penguat lentur D16-125 mm direncanakan untuk menahan momen di pile cap yang terjadi pada 211,6 kN-m. Penurunan total (St) adalah penurunan total langsung (Si) dan penurunan konsolidasi (Sc) yaitu 1,673<15 cm. Penurunan total (St) pada tiang grup memenuhi kondisi yang diizinkan untuk bangunan berdasarkan RSNI Geoteknis.
\end{abstract}

Kata Kunci: Daya dukung pondasi, Pile cap, Group drop, Bored Pile.

\section{PENDAHULUAN}

Gedung kantor Pemerintah Kabupaten (pemkab) Lamongan dibangun guna memberikan pelayanan publik kepada masyarakat Kabupaten Lamongan. Gedung kantor pemkab Lamongan 
dibangun pada area kompleks alun-alun Kota Lamongan. Sama halnya gedung-gedung lainnya, gedung pemkab Lamongan terbagi atas dua bagian yaitu struktur bawah dan struktur atas. Umumnya kestabilan suatu struktur tidak hanya ditentukan oleh struktur atas yang secara langsung menerima beban-beban yang bekerja pada struktur tersebut. Namun ada bagian terpenting dari struktur gedung adalah pondasi yang menjaga kestabilan struktur bagian bawah (Indra Dwi Prasetya ,2018).

Pondasi adalah struktur bangunan paling bawah yang berfungsi untuk menahan dan menyalurkan beban dari atas ke tanah (Candra, n.d.). Pondasi juga berguna untuk penentu letak struktur bangunan diatasnya yang berupa kolom (Candra, Yusuf, \& F, 2018). Sampai saat ini dan waktu yang akan datang pondasi akan masih menjadi struktur terpenting dari sebuah bangunan khususnya pada bangunan gedung (Candra, Cahyo, et al., 2019). Walaupun bukan hal baru, perencanaan dan perhitungan pondasi selalu memerlukan pertimbangan-pertimbangan khusus agar mendapat kualitas dan keamanan yang baik nantinya (Candra, Gardjito, Cahyo, \& Prasetyo, 2019). Berdasarkan jenis tanah dan kedalaman tanah keras, pondasi dibedakan menjadi dua yaitu pondasi dangkal dan pondasi dalam.

Pondasi yang Saat ini digunakan pada proyek pembangunan gedung kantor pemkab Lamongan adalah pondasi dalam jenis tiang pancang (spun pile) yang mempunyai beberapa kelemahan bila di bandingkan dengan pondasi dalam jenis tiang tiang bor (Bored pile). Diantaranya yaitu, proses pemasangan yang sering menimbulkan gangguan suara dan getaran yang membahayakan bangunan disekitarnya, kedalaman tiang yang tidak dapat di variasikal (mengikuti panjang dari pabrik), rawannya patah pada sambungan tiang yang berakibat pada pembengkakat biaya. Permasalahan penting dalam perencanaan pondasi tiang bor adalah besar daya dukung tanah yang mampu menahan beban kerja yang dipikul pondasi. Masalah lainnya adalah mengenai penurunan tanah akibat beban yang dipikul pondasi maupun beban dari pondasi tiang bor itu sendiri sehingga mengakibatkan pemampatan tanah dibawah ujung pondasi.

\section{Tujuan Penelitian}

1. Membandingkan antara gaya aksial yang bekerja dengan daya dukung pondasi.

2. Mengetahui desain pile cap dan pondasi tiang bor.

3. Mengetahui besar penurunan yang terjadi pada pondasi. 


\section{METODE PENELITIAN}

Sebelum melakukan analisa daya dukung pondasi perlu dilakukan analisa pembebanan. Perhitungan beban meliputi beban mati, beban hidup, dan beban gempa yang kemudian dianalisa dengan bantuan progamstaad.pro untuk mempermudah dalam menyediakan data-data untuk perhitungan daya dukung pondasi. Pada rencana daya dukung pondasi ditinjau pada 3 (tiga) kondisi yaitu kondisi tekan, tarik dan horisontal. Tahap awal dilakukan perhitungan daya dukung tiang tunggal sebelum diperoleh kuat dukung tiang kelompok. Pile cap direncanakan bertujuan untuk mengikat dan mempersatukan tiang-tiang. Penurunan total (St)tiang kelompok harus memenuhi syarat aman $<15+600 / \mathrm{B} \mathrm{cm}$, apabila nilai Stmelebihi batas aman maka perlu dilakukan analisa ulang

\section{HASIL DAN PEMBAHASAN}

\section{Analisa Strukur}

Tabel 1. Beban yang bekerja

\begin{tabular}{|ccc|}
\hline \multicolumn{2}{|c|}{ Beban } & Jumlah \\
\hline \multicolumn{2}{|c|}{ Beban mati } & $4,42 \mathrm{kN} / \mathrm{m}^{2}$ \\
& Beban hidup & $2,50 \mathrm{kN} / \mathrm{m}^{2}$ \\
& Beban atap kuda-kuda & \\
$\mathrm{RD}$ & & $1,27 \mathrm{kN}$ \\
$\mathrm{RL}$ & & $0,43 \mathrm{kN}$ \\
\hline \multicolumn{2}{|c}{ Sumber: hasil perhitungan } \\
\hline
\end{tabular}

Tabel 2. Beban yang bekerja

\begin{tabular}{|ccccccccc|}
\hline Lantai & $\begin{array}{c}\text { Wtotal } \\
{[\mathrm{kN}]}\end{array}$ & $\begin{array}{c}\mathrm{Hi} \\
{[\mathrm{m}]}\end{array}$ & $\mathrm{k}$ & $\begin{array}{c}\mathrm{W}_{\mathrm{i}} \mathrm{k}_{\mathrm{i}}^{\mathrm{k}} \\
{[\mathrm{kN} \cdot \mathrm{m}]}\end{array}$ & $\mathrm{Cvx}$ & $\begin{array}{c}\mathrm{V} \\
{[\mathrm{kN}]}\end{array}$ & $\begin{array}{c}\mathrm{Fx} \\
{[\mathrm{kN}]}\end{array}$ & $\begin{array}{c}\text { Fy } \\
{[\mathrm{kN}]}\end{array}$ \\
\hline 1 & 16384,38 & 4.55 & 1,45 & 147748,90 & 0,158 & 5738,2 & 906,5 & 271,95 \\
\hline
\end{tabular}

Tabel 2. Lanjutan

\begin{tabular}{|ccccccccc|}
\hline Lantai & $\begin{array}{c}\text { Wtotal } \\
{[\mathrm{kN}]}\end{array}$ & $\begin{array}{c}\mathrm{Hi} \\
{[\mathrm{m}]}\end{array}$ & $\mathrm{k}$ & $\begin{array}{c}\mathrm{W}_{\mathrm{i}} \mathrm{k}_{\mathrm{i}}^{\mathrm{k}} \\
{[\mathrm{kN} \cdot \mathrm{m}]}\end{array}$ & $\mathrm{CvX}$ & $\begin{array}{c}\mathrm{V} \\
{[\mathrm{kN}]}\end{array}$ & $\begin{array}{c}\mathrm{Fx} \\
{[\mathrm{kN}]}\end{array}$ & $\begin{array}{c}\text { Fy } \\
{[\mathrm{kN}]}\end{array}$ \\
\hline 2 & 17062,56 & 5 & 1,45 & 176436,80 & 0,189 & 5738,2 & 1082,51 & 324,75 \\
3 & 17619,39 & 5 & 1,45 & 182194,76 & 0,195 & 5738,2 & 1117,83 & 335,35 \\
4 & 15587,42 & 4 & 1,45 & 116588,51 & 0,125 & 5738,2 & 715,31 & 214,59 \\
5 & 1319082 & 4 & 1,45 & 98662,76 & 0,105 & 5738,2 & 605,33 & 181,6 \\
\hline
\end{tabular}




\begin{tabular}{|ccccccccc|}
\hline 6 & 13190,82 & 4 & 1,45 & 98662,76 & 0,105 & 5738,2 & 605,33 & 181,6 \\
7 & 12068,05 & 4 & 1,45 & 90264,82 & 0,097 & 5738,2 & 553,81 & 166,14 \\
8 & 3302,98 & 4 & 1,45 & 24705,13 & 0,026 & 5738,2 & 151,58 & 45,47 \\
\hline
\end{tabular}

Sumber: hasil perhitungan

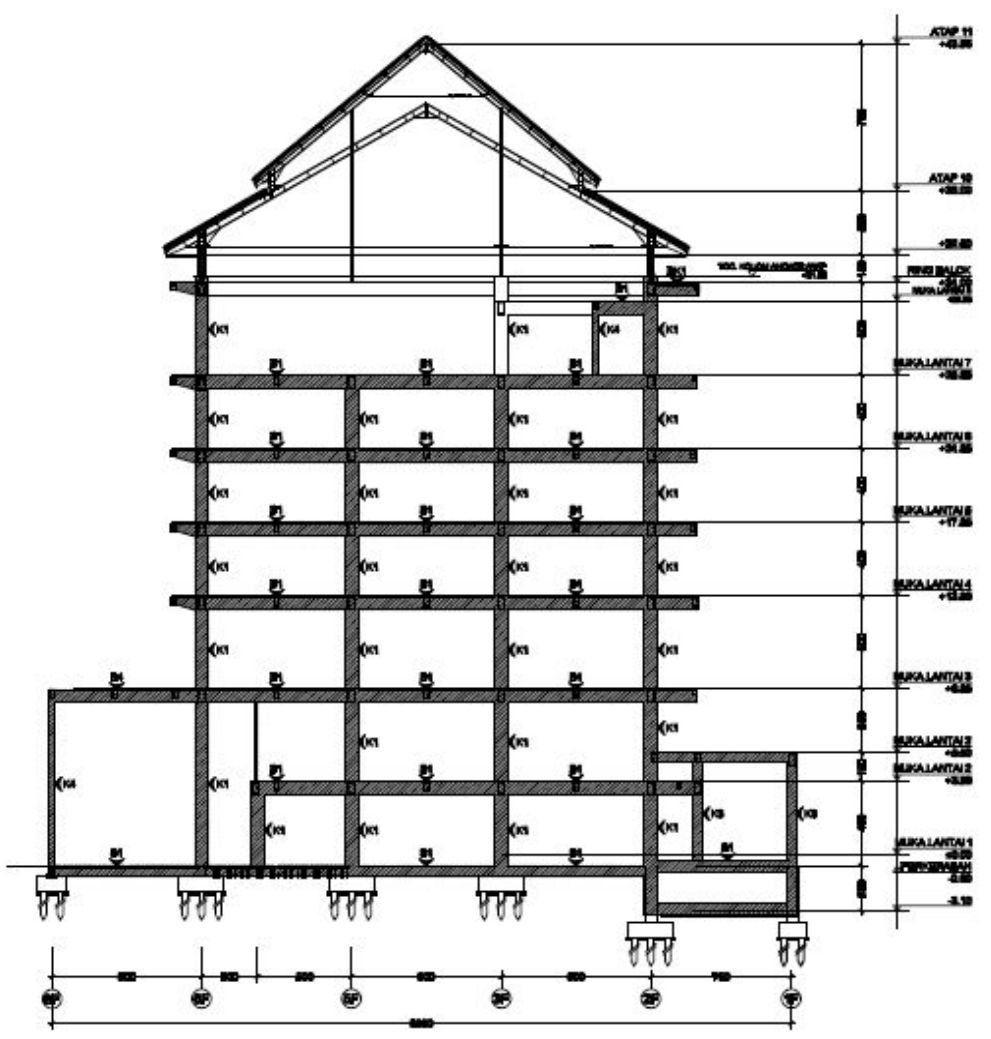

Gambar 1. Permodelan beban arah Y

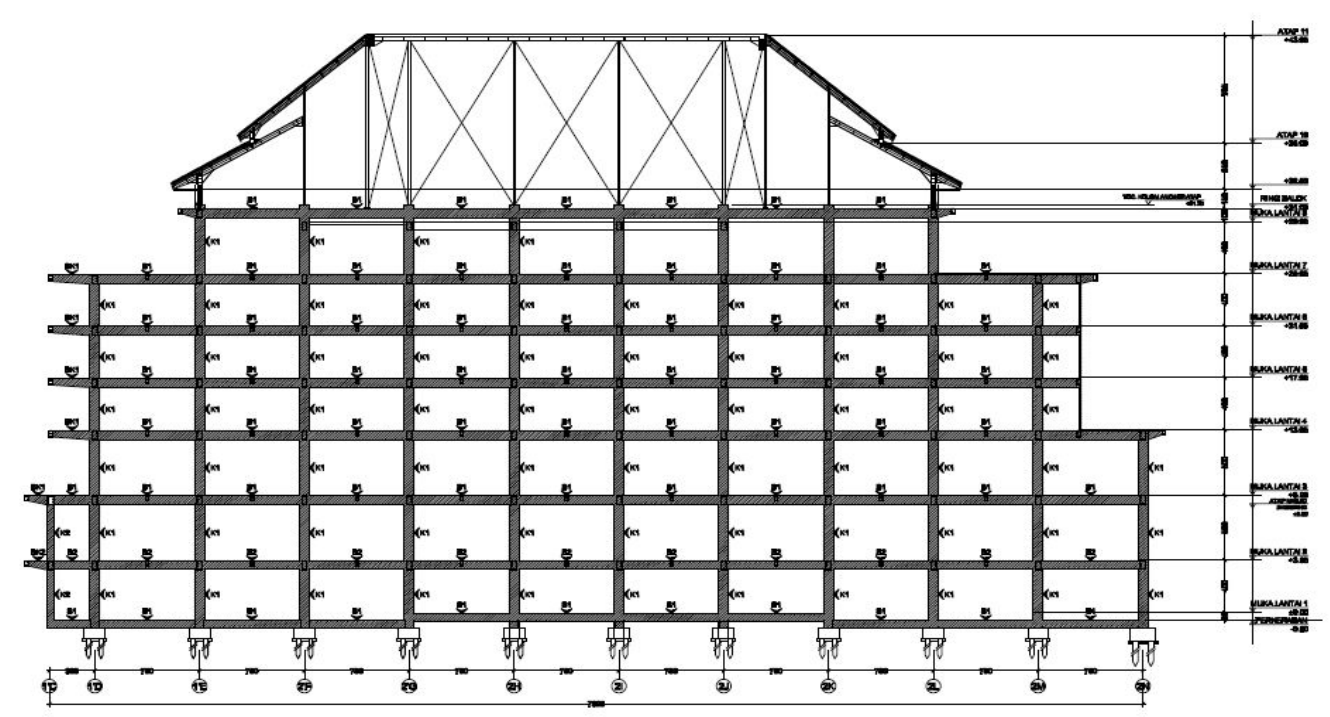

Gambar 2. Permodelan beban arah X 


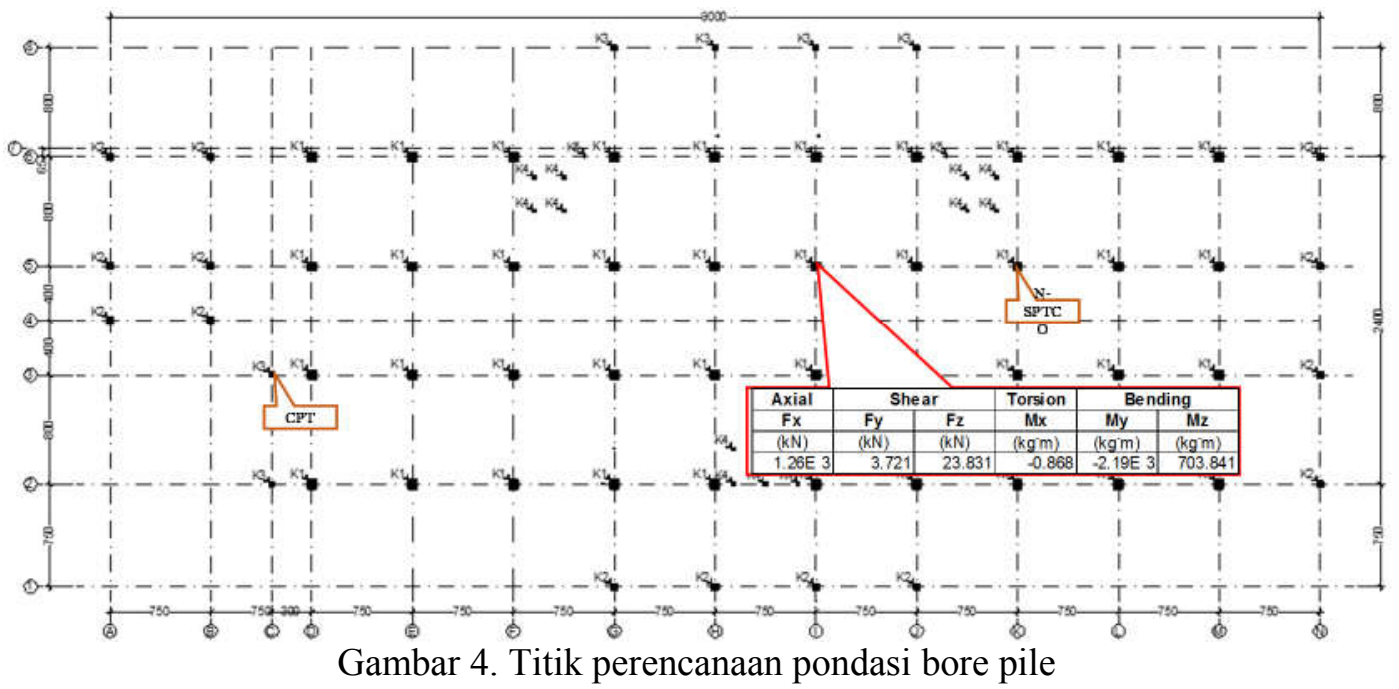

Kombinasi pembebanan menggunakan kombinasi 1,2D + 1,0E +1 , $0 \mathrm{~L}$. Selanjutnya beban-beban tersebut diinput dan dianalisa kedalam progam Staad.Pro. Hasil keluaran dari Staad.Pro pada titik kolom yang ditinjau yaitu titik 5-I diperoleh gaya aksial yang bekerja adalah $1260 \mathrm{kN}$. Kemudian direncanakan daya dukung tiang tunggaldihitung berdasarkan data N-SPT untuk menahan besar gaya aksial yang bekerja.

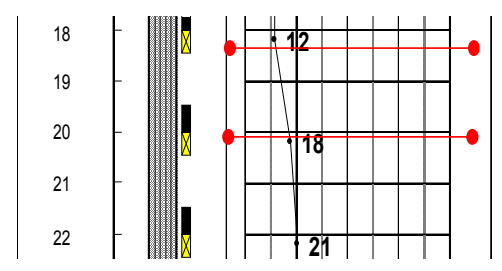

Gambar 5. Kalibrasi harga N

\section{Daya Dukung Tiang Tunggal}

Depth $=20 \mathrm{~m}$

$$
\begin{aligned}
\text { Dtiang } & =0,40 \mathrm{~m} \\
\overline{\mathrm{N}} & =\frac{\mathrm{N} 1+\mathrm{N} 2}{2} \\
& =\frac{18+17}{2} \\
& =17,50
\end{aligned}
$$

Panjang ekivalen tiang $=0,80 \mathrm{~m}$

Dari Gambar 6 didapat nilai $\mathrm{qd} / \mathrm{N}$ adalah sebesar 11. Kemudian qd dihitung berdasarkan persamaan dibawah.

qd $\quad=17,50 \times 11=1925 \mathrm{kN} / \mathrm{m}^{2}$

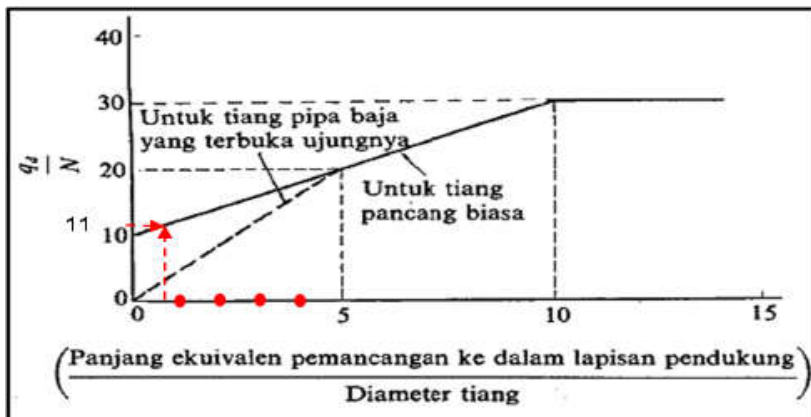


Gambar 6. Diagram intensitas daya dukung ultimit tanah pondasi pada ujung tiang Tabel 3. Gaya gesek keliling tiang

\begin{tabular}{|c|c|c|c|c|c|}
\hline Depth m & Li m & Deskripsi tanah & $\mathrm{N}$ & $f i \mathrm{t} / \mathrm{m}^{2}$ & $\begin{array}{c}f i \times L i \\
\mathrm{t} / \mathrm{m}\end{array}$ \\
\hline 0 & \multirow[b]{3}{*}{2} & & \multirow{4}{*}{4} & \multirow{4}{*}{0,8} & \multirow{4}{*}{1,6} \\
\hline 1 & & Urugan batu kapur & & & \\
\hline 2 & & & & & \\
\hline 3 & \multirow{2}{*}{2} & Lanau kelempungan & & & \\
\hline 4 & & \multirow{5}{*}{$\begin{array}{l}\text { Lanau kelempungan } \\
\text { sedikit pasir dan } \\
\text { kulit kerang }\end{array}$} & 5 & 2,5 & 5 \\
\hline $\begin{array}{l}5 \\
6\end{array}$ & 2 & & 7 & 3,5 & 7 \\
\hline 7 & \multirow{2}{*}{2} & & \multirow{3}{*}{10} & \multirow{3}{*}{5} & \multirow{3}{*}{10} \\
\hline 8 & & & & & \\
\hline 9 & \multirow{2}{*}{2} & & & & \\
\hline 10 & & \multirow{9}{*}{ Lanau kelempungan } & 14 & 12 & 24 \\
\hline $\begin{array}{l}11 \\
12\end{array}$ & 2 & & 10 & 10 & 20 \\
\hline 13 & \multirow{2}{*}{2} & & & & \\
\hline 14 & & & 16 & 12 & 24 \\
\hline 15 & \multirow{2}{*}{2} & & & & \\
\hline 16 & & & 12 & 12 & 24 \\
\hline 17 & \multirow[t]{2}{*}{2} & & & & \\
\hline 18 & & & 12 & 12 & 24 \\
\hline $\begin{array}{l}19 \\
20\end{array}$ & 2 & & 18 & 12 & 24 \\
\hline Jumlah $\sum$ & & & & & 139,60 \\
\hline
\end{tabular}

Sumber: hasil perhitungan

$$
\begin{aligned}
& \mathrm{Qa}=\frac{\mathrm{q}_{\mathrm{d}} \times \mathrm{Ab}}{3}+\frac{\Sigma l i . f i \times \mathrm{U}}{5} \\
& =\frac{192,5\left(1 / 4 \times \pi \times 0,40^{2}\right)}{3}+\frac{1396(\pi \times 0,40)}{5} \\
& =431,49 \mathrm{kN} \\
& \mathrm{Pta}=\frac{\sum l i . f i \times \text { Ast } \times 0,70}{5} \times \mathrm{Wp} \\
& \quad=\frac{1369(\pi \times 0,40) \times 0,70}{5}+60,32 \mathrm{kN} \\
& =305,92 \mathrm{kN}
\end{aligned}
$$

\section{Daya Dukung Tiang Kelompok}

- Daya dukung tekan

$$
\begin{aligned}
& \mathrm{Qg}=\eta \times \mathrm{n} \times \mathrm{Qa} \\
& \quad=0,795 \times 5 \times 431,49 \\
& =1715,52 \mathrm{kN} \geq \mathrm{Pu}=1260 \mathrm{kN} \ldots .
\end{aligned}
$$

- Daya dukung tarik

$\mathrm{Pg}=\eta \times \mathrm{n} \times \mathrm{Pta}$

$=0,795 \times 5 \times 305,92$

$=1216,27 \mathrm{kN}$

- Daya dukung horisontal 


$$
\begin{aligned}
\mathrm{Hu} & =\frac{2 \mathrm{M}_{\mathrm{y}}}{3 \mathrm{D} / 2+\mathrm{f} / 2} \\
& =\frac{2 \times 21,9}{3 \times 0,40 / 2+0,00712 \mathrm{Hu} / 2} \\
& =\frac{43,80}{0,60+0,00356 \mathrm{Hu}} \\
43,80 & =0,60+0,00356 \mathrm{Hu}^{2} \\
\mathrm{Hu} & =110,14 \mathrm{kN} \geq \frac{\mathrm{Fx}}{\mathrm{np}}=77,94 \mathrm{kN} \ldots . \mathrm{V}
\end{aligned}
$$

\section{Distribusi Beban Maksimum}

$\mathrm{P}=\frac{\sum \mathrm{V}}{\mathrm{n}} \pm \frac{\mathrm{My} \mathrm{X}_{\max }}{\mathrm{n}_{\mathrm{y}} \sum \mathrm{X}^{2}} \pm \frac{\mathrm{Mx}_{\max }}{\mathrm{n}_{\mathrm{x}} \sum \mathrm{Y}^{2}}$

$\mathrm{P}_{\max }=258,44 \leq$ Qall $=431,49 \mathrm{kN} \ldots \checkmark$

Pmin $=245,55 \leq$ Qall $=431,49 \mathrm{kN} \ldots \checkmark$

\section{Pile Cap}

Kebutuhan luas tulangan (ASperlu) untuk pile cap adalah sebesar $2485 \mathrm{~mm}^{2}$. Direncanakan tulangan lentur D19-125 dengan ASpakai $2551 \mathrm{~mm}^{2}$ untuk menahan momen ultimit yang terjadi sebesar $84,63 \mathrm{kN}-\mathrm{m}$.

Kontrol kapasitas momen terhadap momen ultimit :

$\varnothing \mathrm{Mn}=564,37 \geq \mathrm{Mu}=84,63 \mathrm{kN}-\mathrm{m} \ldots \mathrm{V}$

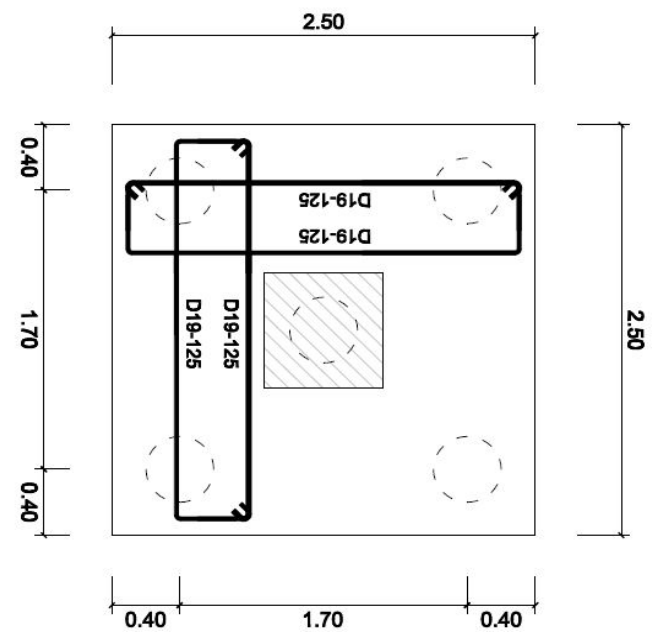

Gambar 7. Penulangan pile cap

- Perhitungan geser satu arah :

$\varnothing \mathrm{Vc}=0,75 \times 1540,60$

$=1155,47 \mathrm{kN} \leq \mathrm{Vu}=516,89 \mathrm{kN}$

...V (tidak perlu tulangan geser)

- Perhitungan geser dua arah :

$\varnothing \mathrm{Vc}=0,75 \times 6818,63$

$=5113,97 \mathrm{kN} \leq \mathrm{Vu}=1292,22 \mathrm{kN}$

.... $\checkmark$ (tidakperlu tulangan geser) 


\section{Perencanaan Tiang Bor}

- Rencana tulangan longitudinal :

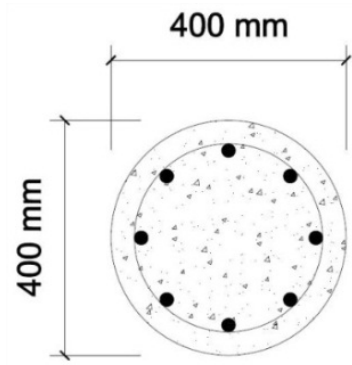

Gambar 8. Penampang tiang $40 \mathrm{~cm}$

$$
\begin{aligned}
& \mathrm{Ag}=1 / 4 \times \pi \times \mathrm{D}^{2}=125663,71 \mathrm{~mm}^{2} \\
& \mathrm{ASmin}=0,01 \times \mathrm{Ag}=1256,64 \mathrm{~mm}^{2} \\
& \mathrm{ASmax}^{2}=0,08 \times \mathrm{Ag}=10053,10 \mathrm{~mm}^{2}
\end{aligned}
$$

Luas tulangan longitudinal rencana tidak disarankan kurang dari ASmin dan tidak lebih besar dari ASmax. Maka direncanakan tulangan longitudinal 8 D16 (Ast $\left.=1608,50 \mathrm{~mm}^{2}\right)$ dan tulangan spiral Ø10-75 mm (BJTP 24).

$$
\begin{aligned}
\text { As } & =\text { As' } \\
& =1 / 2 \times \text { Ast }=804,25 \mathrm{~mm}^{2}
\end{aligned}
$$

- Kuat beton pengisi :

Analisa penampang dalam bentuk bulat diekivalenkan sehingga menjadi penampang persegi.

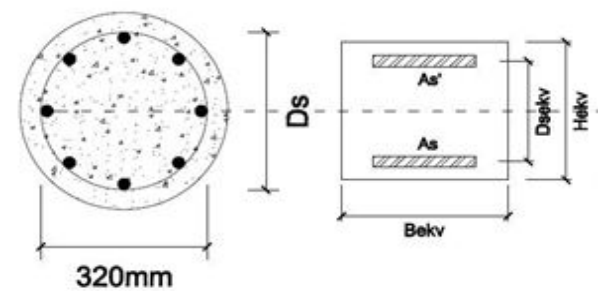

Gambar 9. Penampang ekivalen

Pemeriksaan Pub dan Mub :

$\mathrm{Pub}=1195,51 \mathrm{kN} \geq \mathrm{P}_{\max }=258,44 \mathrm{kN} \ldots . . \vee$ (terjadi keruntuhan tarik)

$\mathrm{Mub}=178,99 \mathrm{kN}-\mathrm{m}$

Kontrol eksentrisitas :

$$
\begin{aligned}
& \mathrm{e}=\frac{\mathrm{Mu}}{\mathrm{Pu}}=\frac{21,90}{258,44}=0,085 \mathrm{~m} \\
& \mathrm{eb}=\frac{\mathrm{Mub}}{\mathrm{Pub}}=\frac{178,99}{1195,51}=0,149 \mathrm{~m}
\end{aligned}
$$

Diperoleh bahwa e $\leq$ eb,maka termasuk tiang dengan "eksentrisitas kecil".

$\varnothing \mathrm{Pn} \quad=1951,34 \geq \mathrm{Pmax}=258,44 \mathrm{kN} . . . \checkmark$

\section{Penurunan Pondasi}

Saat pondasi tiang dibebani, tanah dibawah ujung tiang akan mengalami penurunan. Penurunan dibagi menjadi 2 macam, yaitu: penurunan segera, penurunan konsolidasi. 
- Penurunan segera

Penurunan segera adalah penurunan akibat massa tanah yang tertekan dan terjadi segera setelah terjadi pemberian beban.

$$
\begin{aligned}
\text { Si } & =\mu_{1} \times \mu_{0} \times \frac{\mathrm{q} \times \mathrm{B}}{\mathrm{E}} \\
& =0,50 \times 0,48 \times \frac{2,72 \times 16,20}{1500} \\
& =0,887 \mathrm{~cm}
\end{aligned}
$$

- Penurunan konsolidasi

Penurunan konsolidasi terjadi akibat pengurangan kelebihan tekanan air pori yang meninggalkan rongga pori pada lapisan tanah yang tertekan.

$$
\begin{aligned}
\mathrm{Sc} & =\frac{\mathrm{Cc}}{1+\mathrm{e}_{0}} \times \log \frac{\mathrm{Po}+\Delta \mathrm{p}}{\text { Po }} \times \mathrm{H} \\
& =\frac{0,149}{1+1,344} \times \log \frac{37,25+0,641}{37,25} \times 16,67 \\
& =0,785 \mathrm{~cm}
\end{aligned}
$$

- Penurunan izin

Penurunan total merupakan jumlah dari penurunan segera dan penurunan konsolidasi.Nilai Stotal harus lebih kecil dari Sizin untuk memenuhi syarat aman penurunan tiang kelompok.

$$
\begin{aligned}
\text { Sizin } & =15+\frac{B}{600} \\
& =15,20 \geq \text { Stotal }=1,673 \mathrm{~cm} \ldots \vee
\end{aligned}
$$

\section{KESIMPILAN DAN SARAN}

\section{Kesimpulan}

Tugas akhir ini disusun guna merencanakan kuat dukung pondasi tiang bor terhadap beban aksial yang bekerja akibat beban struktur atas. Yang digunakan sebagai pembanding dengan pondasi tiang awal yaitu tiang pancang. Dalam perencanaan pondasi ini memakai data tanah N-SPT untuk menghitung daya dukung pondasi. Pemakaian 5 tiang bor berdiameter 40 cm dengan kedalaman 20 meter mampu menghasilkan daya dukung sebesar 1715,52 kN dan mampu menahan beban aksial yang terjadi sebesar $1260 \mathrm{kN}$. Penurunan yang terjadi pada kelompok tiang adalah $1,673 \mathrm{~cm}$ dan dirasa sangat aman karena masuk dalam persyaratan $\leq 15$ $+\mathrm{B} / 600 \mathrm{~cm}$. Sedangkan perencanaan pondasi awal menggunakan 5 tiang pancang dengan kedalaman $21 \mathrm{~m}$

\section{Saran}


Dalam perencanaan tugas akhir ini penulis memakai data tanah N-SPT untuk perhitungan daya dukung pondasi. Agar lebih Spesifik perhitungan daya dukung pondasi perlu juga dibandingkan dengan data tanah lain, misal CPT atau sejenisnya

\section{DAFTAR PUSTAKA}

[1] Budi, Gogot Setya. 2011. Pondasi Dangkal. Yogyakarta: C.V Andi Offset.

[2] Bowles, J.E. 1988. Dalam Jurnal Indra Dwi prasetya 2018Analisis dan Desain Pondasi. Jakarta: Erlangga.

[3] Candra, A. I. (n.d.). ANALISIS DAYA DUKUNG PONDASI STROUS PILE PADA PEMBANGUNAN GEDUNG MINI HOSPITAL UNIVERSITAS KADIRI Agata. Ukarst, 1, 63-70.

[4] Candra, A. I., Cahyo, Y., Ridwan, A., Winarto, S., Gardjito, E., Siswanto, E., ... Kadiri, U. (2019). PENGECEKAN KELAYAKAN BANGUNAN GEDUNG SMA NEGERI 1 KOTA KEDIRI YANG DIGUNAKAN UNTUK AKTIFITAS. 2(2), 108-116.

[5] Candra, A. I., Gardjito, E., Cahyo, Y., \& Prasetyo, G. A. (2019). Pemanfaatan Limbah Puntung Rokok Filter Sebagai Bahan Campuran Beton Ringan Berpori. UKaRsT, 3(1), 82-89.

[6] Candra, A. I., Yusuf, A., \& F, A. R. (2018). STUDI ANALISIS DAYA DUKUNG PONDASI TIANG PADA PEMBANGUNAN GEDUNG LP3M. 3(2), 166-171.

[7] Dipodusodo, Istimawan. 1994. Struktur Beton Bertulang Berdasarkan SK SNI T-15-1991-03 Departemen Pekerjaan Umum RI. Jakarta: Gramedia Pustaka Utama.

[8] Hardiyatmo, H.C. 2002. Teknik Pondasi 1. Edisi ke-2. Yogyakarta: Beta Offset.

[9] Hardiyatmo, H.C. 2008. Teknik Pondasi 2. Edisi ke-4.

[10] Pamungkas, A. dan Harianti, E. 2013. Desain Pondasi Tahan Gempa. Yogyakarta: C.V Andi Offet.

[11] Santoso, B. dkk. 1998.Dalam Jurnal Indra Dwi prasetya 2018Mekanika Tanah Lanjutan. Jakarta: Gunadarma.

[12] Sardjono. 1996. Pondasi Tiang Pancang Jilid I. Edisi ke-3. Surabaya: Sinar Wijaya.

[13] Sardjono. 1988. Pondasi Tiang Pancang Jilid I. Edisi ke-1. Surabaya: Sinar Wijaya.

[14] Nakazawa K. 1983 Dalam Jurnal Indra Dwi prasetya 2018Dalam Jurnal Indra Dwi prasetya 2018Pondasi Tiang pancang.

[15] SNI 03-1727:1989 Pedoman Perencanaan Pembebanan Untuk Rumah dan Gedung.

[16] SNI 03-2847:2002 Tata Cara Perhitungan Struktur Beton Untuk Bangunan Gedung. Jakarta: Gd. Manggala Wanabakti.

[17] SNI 1726:2012 Tata Cara Perencanaan Ketahanan Gempa Untuk Struktur Bangunan Gedung dan Non Gedung. Jakarta: Gd. Manggala Wanabakti.

[18] SNI 1727:2013 Beban Minimum Untuk Perancangan Bangunan Gedung dan Struktur Lain. Jakarta: Gd. Manggala Wanabakti.

[19] SNI 2847:2013 Persyaratan Beton Struktural untuk Bangunan Gedung. Jakarta: Gd. Manggala Wanabakti.

[20] Sosrodarsono, S. dan Nakazawa, K. 2000. Mekanika Tanah \& Teknik Pondasi. Edisi ke-7. Jakarta: PT Pradnya Pramita.

[21] Wininda Else Indana. 2018. Studi Perencanaan Pondasi Tiang Bor Pada Hotel Rayz Malang, Skripsi Tidak Diterbitkan. Malang. Progam Sarjana Universitas Muhammadiyah Malang.

[22] Indra Dwi Prasetya. 2018. Studi Perencanaan Pondasi Tiang Pancang (Spun pile) pada gedung pemerintahan kabupaten lamongan, Skripsi Tidak Diterbitkan. Malang. Progam Sarjana Universitas Muhammadiyah Malang. 